\title{
Correction to: Nondestructive evaluation of egg-to-adult development and feeding behavior of the bamboo powderpost beetle Dinoderus minutus using X-ray computed tomography
}

\author{
Hiroki Watanabe ${ }^{1} \cdot$ Yoshiyuki Yanase $^{1} \cdot$ Yoshihisa Fujii $^{1}$
}

Published online: 20 February 2018

(c) The Author(s) 2018. This article is an open access publication

\section{Correction to: J Wood Sci (2017) 63:506-513 https://doi.org/10.1007/s10086-017-1642-3}

The article Nondestructive evaluation of egg-to-adult development and feeding behavior of the bamboo powderpost beetle Dinoderus minutus using X-ray computed tomography, written by Hiroki Watanabe, Yoshiyuki Yanase and Yoshihisa Fujii, was originally published Online First without open access. After publication in volume 63, issue 5, page 506-513 the author decided to opt for Open Choice and to make the article an open access publication. Therefore, the copyright of the article has been changed to (C) The Author(s) 2018 and the article is forthwith distributed under the terms of the Creative Commons Attribution 4.0
International License (http://creativecommons.org/licenses/ by/4.0/), which permits use, duplication, adaptation, distribution and reproduction in any medium or format, as long as you give appropriate credit to the original author(s) and the source, provide a link to the Creative Commons license, and indicate if changes were made.

Open Access This article is distributed under the terms of the Creative Commons Attribution 4.0 International License (http://creativeco mmons.org/licenses/by/4.0/), which permits unrestricted use, distribution, and reproduction in any medium, provided you give appropriate credit to the original author(s) and the source, provide a link to the Creative Commons license, and indicate if changes were made.
The original article can be found online at https://doi.org/10.1007/ s10086-017-1642-3.

\footnotetext{
Hiroki Watanabe

watanabe@h3news1.kais.kyoto-u.ac.jp

1 Graduate School of Agriculture, Kyoto University, Kitashirakawaoiwake-cho, Sakyo-Ku, Kyoto 606-8502, Japan
} 